Elisabeth Hufnagel

\title{
Adapting the Concept of Proportio to Rhythm in the Ars subtilior: Ugolino da Orvieto's Compositions and his Statements on Proportion Signs in Codex Casanatense 2151
}

\begin{abstract}
Music manuscripts as well as music treatises from the early fifteenth century bear witness to major adaptations in music notation. The compositions of the so-called Ars subtilior feature notational innovations (e.g. new note shapes, notes in differently coloured ink, and proportion signs) which enable the depiction of complex rhythms. Simultaneously, discussions of notational innovations appear in music treatises, which were used in contexts of teaching and learning. This paper aims to investigate to what extent the adaptations in music treatises and compositions are interrelated, focusing on the manuscript Rome, Biblioteca Casanatense, 2151, which transmits three songs as well as the music treatise Declaratio musicae disciplinae. Both songs and treatise are attributed to the Italian music theorist and composer Ugolino da Orvieto (c. 1380-1452). A comparison of proportion signs contained in Ugolino's songs and his statements on music notation will allow us to explore the question whether teachings on music reflect actual notational practice and vice versa.
\end{abstract}

\section{Introduction}

When asked about their notion of music from the Western European Middle Ages, most people reply that they think of simple, slow, and archaic pieces, which are performed by a handful of monks in a large cathedral. Many are unaware of the elaborate and highly refined compositions of the Ars subtilior. ${ }^{1}$ This particular musical style flourished in the decades surrounding the year 1400 in the regions

1 The term Ars subtilior ('more subtle art') designating a musical style was proposed by Ursula Günther (1963) in her renowned article on the post-Machaut generation of composers. Although it has also been criticised in the past (cf. for example Haas 1982, 385-386), it has become commonly accepted in recent decades and is even used to designate an epoch.

¿ Open Access. (C) 2021 Elisabeth Hufnagel, published by De Gruyter. (cc) Br-NC-ND This work is licensed under the Creative Commons Attribution-NonCommercial-NoDerivatives 4.0 International License. https://doi.org/10.1515/9783110741124-021 
of today's southern France and northern and central Italy and it is most notably distinguished by the compositions' rhythmic complexity. ${ }^{2}$ The corpus of Ars subtilior pieces that have survived is predominantly comprised of three-part secular French songs notated in black mensural notation ${ }^{3}$ and transmitted in decorated manuscripts.

However, music manuscripts are not the only music-related manuscript transmissions from that period which have survived into our times. Quite the contrary, hundreds of manuscripts containing music treatises account to the fact that music was also an integral part of education in the late Middle Ages and early Renaissance. Yet, music as it was taught in Western European educational institutions at that time constituted a subject which is fundamentally different from our modern idea of it. Music was one of the four disciplines of the quadrivium, which also included arithmetic, geometry, and astronomy and thus belonged to the four mathematical arts. ${ }^{4}$ Surviving manuscripts bear witness to a scholastic tradition in which musica was considered to be a scientia. As such music was primarily regarded from a mathematical and philosophical perspective. This socalled musica speculativa harks back to Ancient Greek philosophers, especially Pythagoreans and Neo-Pythagoreans, and usually comprises a study of numbers and numerical proportions, which is closely linked to discussions of musical intervals and calculations thereof. In medieval music theory, practical music (musica practica) regularly only came second. ${ }^{5}$ A distinction was made between a musicus, who had undergone a musical education in the quadrivial discipline, and a cantor, who was a mere practitioner. ${ }^{6}$ However, one can witness a departure

2 Other distinguishing features of the Ars subtilior are described in Fallows 1996, $21-23$.

3 Mensural notation is a general term for the system of musical notation that evolved in the decades before 1300 and was used for the transmission of European polyphonic vocal music in the following three centuries. The innovative feature of this notation when compared to older music notation systems, e.g. neumatic notation, was its measurability, i.e. each note had a defined duration in terms of numerical proportions between the different note values or, practically speaking, when sung, one note sounded, for example, three times as long as a note of a smaller degree. The specific term 'black mensural notation' refers to the fact that the note shapes are not void as, for example, some notes in modern musical notation.

4 The combination of trivium (grammar, rhetoric, and logic) and quadrivium constituted the seven liberal arts, which formed the foundation of Western European education until the Renaissance. Scholars were expected to study the seven liberal arts before entering higher education, e.g. theology, medicine, or law.

5 For an account of the differences between musica practica and musica speculativa in music treatises see Herlinger 2001, esp. 297-300. An exhaustive bibliography of literature discussing the differentiation can also be found in Dyer 2007, 3 n. 1 .

6 On this distinction see, for example, Reimer 1978, esp. 18-28. 
from the Platonic-Pythagorean tradition in music theory from the fourteenth century onwards. ${ }^{7}$ Late medieval and early Renaissance music treatises often contain both speculative approaches as well as chapters on practical aspects, such as instructions on music notation, e.g. descriptions and illustrations of signs and note shapes, as well as voice-leading techniques - called counterpoint - in polyphonic music.

With the evolution of mensural notation in Europe in the last decades of the thirteenth century proportions are increasingly discussed in rhythmic contexts. ${ }^{8}$ This development can be described as the central adaptation process in music treatises of the thirteenth, fourteenth, and fifteenth centuries. Before that time proportions had only been treated in the context of musical intervals and their derivation, i.e. in the realm of musica speculativa. The most important intervals in Western music are based on simple numerical proportions. For example, when the simplest of all proportions, dupla (2:1) proportion, is applied to a string - i.e. one first plucks the whole string, then presses down in the middle of it and plucks one of the halves - the half will sound an octave above the whole string. Similarly, sesquialtera (3:2) proportion results in a perfect fifth and sesquitertia (4:3) proportion in a perfect fourth. All other musical intervals in Western music can be derived from these three proportions with the help of basic arithmetic operations. However, in measured music, proportions also occur in rhythmic contexts: A note can sound twice as long as another, or three notes can have the same duration as two others, etc. Several fourteenth-century authors mention this circumstance. ${ }^{9}$ General adaptation can therefore be observed in the gradual adoption of the teachings of proportions in contexts concerned with musica practica, for example in treatises or chapters on mensural notation.

As already mentioned, Ars subtilior music is particularly distinguished by its rhythmic complexity. Incidentally, one particular Ars subtilior ballade was once described as 'the acme of rhythmic intricacy in the entire history of music' ${ }^{10}$ Rhythmic complexity in Ars subtilior music is primarily evoked by proportional rhythms and syncopation. Proportional rhythms are in principle comparable to

7 For a summary of these developments see Tanay 1999, 1-13.

8 For a detailed account of late thirteenth- and fourteenth-century treatises mentioning proportion in rhythmic contexts see Gallo 1984, 334-356.

9 Cf. Gallo 1984, 334-336.

10 Apel 1942, 432. In this quotation, Willi Apel was referring to Zacara da Teramo's ballade Sumite karissimi. As Fallows (1996, 22) notes, this statement was made before Karlheinz Stockhausen (1928-2007) or Pierre Boulez (1925-2016) had published any compositions featuring the extremely complex rhythms typical of their oeuvre, but agrees that 'it was true at the time'. 
duplets, triplets, quadruplets, etc. in modern notation. Today, these rhythms are indicated by small Arabic numerals and the notes to which the proportion should be applied are either grouped by beams or by brackets. However, the notation of Ars subtilior music was less standardised and therefore more ambiguous. A large variety of notational devices were applied in order to depict a comparatively small set of rhythmic proportions, mostly sesquialtera (3:2) and sesquitertia (4:3) proportion. Thus, Ars subtilior compositions often feature new note shapes, notes in differently coloured ink, or proportion signs. Proportion signs can be geometric shapes (e.g. circles or semicircles), Arabic numerals, or stacked Arabic numerals (i.e. fractions without the line drawn between them), and they indicate the beginning of a section with proportional rhythms.

It is not surprising that discussions of these notational devices also appear in music treatises. New note shapes and note colours were already discussed in fourteenth-century treatises while proportion signs make their first appearance in Prosdocimus de Beldemandis' Expositiones tractatus practice cantus mensurabilis magistri Johannis de Muris of $1404 .{ }^{11}$ It is evident that there was adaptation in music treatises as well as music notation concerning the notation of rhythmic proportion. It is less apparent, however, how far these two adaptation processes are interrelated. Are the discussions of notational devices in music treatises prescriptive or descriptive? Did Ars subtilior composers - or perhaps even scribes first invent new notational devices and did theorists then discuss these innovations or was it the other way around? It also seems conceivable that new notational devices were invented by theorists in order to standardise notation and that the theorists' suggestions were then gradually implemented by composers and scribes. In how far do the teachings of music treatises reflect on actual notational practice? Finding answers to these questions is complicated by the fact that research involving medieval and Renaissance sources deals with many uncertainties, as for example the origin of a manuscript, the identity of a composer or author, and so forth. Since we have to assume regional and cultural differences in the notation of mensural music, different sources of unknown origin or authorship are unsuited for the comparison of music treatises and music manuscripts.

11 For an edition of this passage see Gallo 1966, 141-142. Note that Busse Berger's often-cited monograph (1993, 164) mistakenly calls Prosdocimus’ 1408 Tractatus practice cantus mensurabilis the first treatise mentioning proportion signs. 


\section{The manuscript Cas and its contents}

The manuscript Rome, Biblioteca Casanatense, 2151 (henceforth Cas), however, constitutes an exception. It contains the music treatise Declaratio musicae disciplinae (henceforth Declaratio), ${ }^{12}$ which includes a discussion of notational devices to indicate rhythmic proportion, as well as three Ars subtilior songs (see Figs 2-6) featuring such devices, namely coloration and proportion signs. Both treatise and songs are attributed to the same author, namely Ugolino di Francesco da Orvieto, who was a cleric, musical theorist, composer, and singer. Due to this congruent authorship of treatise and compositions, Cas is a particularly suitable candidate for a comparison of statements from the music treatise and actual music notation.

Ugolino lived and worked in the Italian cities of Forlì, Florence, and Ferrara between c. 1380 and 1452 and it is assumed that he wrote his treatise around the year 1430, although the autograph is lost. ${ }^{13}$ Ugolino seems to have enjoyed a high reputation within the Italian musical world, as can be deduced from the praise of his contemporary Flavio Biondo: 'And what shall I say of Ugolino Urbevetano? Born and raised in Forlì, by universal consent he surpasses all the musicians of our time, and the book he has published on music will eclipse the labors of all who have written before him.'14

The manuscript Cas is one of only two complete copies of the Declaratio and it is the only copy transmitting Ugolino's three compositions. ${ }^{15}$ Unfortunately,

12 With 427 chapters the Declaratio is one of the most comprehensive music treatises of the fifteenth century. It comprises five books: 1: musica plana (fundamentals of music and the modes based on Boethius and Marchetto da Padova); 2: melodiatae musicae seu contrapuncti ratio (counterpoint based on Prosdocimus de Beldemandis); 3: musica mensurata (mensural notation based on Johannes de Muris); 4: omnium generum proportiones (teachings of proportions based on Boethius); 5: musica speculativa (cf. Herlinger 2001, 255).

13 Cf. Seay 1955, 118 and MacCarthy 2014, 408. Amongst others, Lockwood (2009, 85) also considers a later date of completion of the treatise possible. The latest biographical account of Ugolino da Orvieto can be found in Janke 2016, 127-134, esp. 127-128. MacCarthy 2015 gives c. 1390 as the year of his birth.

14 'Quid quod Ugolinus cognomine Urbevetanus Forlivii genitus et nutritus ornnes aetatis nostrae musicos sine contradictione superat, editusque ab eo de musica liber haud secus omnium qui ante se scripserunt labores obscurabit [...].' This commendation was first reported by Haberl 1895, 43. Translation taken from MacCarthy 2014, 402.

15 For a detailed description of the manuscript see Seay 1955, 128-133. Cas also contains Ugolino's monochord treatise Tractatus monochordi, which is only transmitted in Cas, London, British Library, Add. 33519, and Rome, Biblioteca Apostolica Vaticana, Urbin. lat. 258. The latter manuscript is the only other complete copy of the Declaratio. 
neither scribe nor origin of the Cas copy of the treatise have yet been identified but Albert Seay has stated that the scribe's Italian humanistic book hand points towards a copying date around the middle of the fifteenth century. ${ }^{16}$ The three songs are part of a gathering of six folios (fols $340^{\mathrm{r}}-345^{\mathrm{v}}$ ), which also contains a part of the index to the treatise preceding the compositions. ${ }^{17}$ Therefore, the three songs were presumably entered after the index was completed..$^{18}$ It can be ascertained that the music scribe is the same for all three compositions and that he was in all likelihood also responsible for copying the musical examples within the treatise. ${ }^{19}$ This would imply that treatise and compositions form one codicological unit. ${ }^{20}$ Hence, the songs are in all probability not as far removed from the copying of the treatise as their position after the index as appendix to the manuscript might suggest.

Furthermore, it can be assumed with reasonable certainty that the author of the treatise and the composer are the same person, namely Ugolino, since each song carries the attribution 'Idem Ugolinus' and he is identified as author in Cas as well as in several other surviving copies of the treatise. Cas therefore provides suitable material for the study of adaptation processes concerning the notation of rhythmic proportions in the Ars subtilior. This paper aims to compare Ugolino's remarks on that issue in the Declaratio with his Cas compositions.

Cas contains the following three compositions: a Latin ballade and two Italian ballate (see Table 1 and Figs 2-6). As already stated, all three works are unique to Cas and do not appear in other copies of the Declaratio nor in any other surviving music anthology. ${ }^{21}$ Until the discovery of the San Lorenzo palimpsest, which contains five further pieces by Ugolino, the Cas compositions were believed to be the only surviving music by the composer. ${ }^{22}$

16 Cf. Seay 1955, 129.

17 Cf. Fallows 2010, 19.

18 Cf. Janke 2016, 136.

19 A comparison of the clefs and custodes in the musical example on fol. $102^{\mathrm{v}}$ of the treatise with the compositions in Cas strongly suggest that the same scribe was at work in these different sections of the manuscript. See note 24 below for a comment on the manuscript's foliation.

20 It should be noted, however, that the text scribe of the three songs is not the text scribe of the treatise.

21 Three other copies of the Declaratio contain music, though none of the compositions are attributed to Ugolino as in Cas. The manuscript Oxford, Bodleian Library, Canon. Misc. 42 includes three anonymous two-voice Italian songs (fols $185^{\mathrm{V}}-188^{\mathrm{r}}$ ), Turin, Biblioteca Nazionale Universitaria, G.IV.31 contains a textless anonymous three-voice song (fol. $97^{\mathrm{v}}$ ), and Porto, Biblioteca Pública Municipal, 714 contains 19 polyphonic songs of various composers (fols $51^{\mathrm{v}}-79^{\mathrm{r}}$ ).

22 The discovery of musical compositions in the manuscript Florence, Archivio del Capitolo di San Lorenzo, 2211 (henceforth SL) was first reported by D’Accone 1984. Due to overwriting on 
Unlike modern polyphonic songs, in which voice parts are usually arranged in the so-called score format, the compositions in Cas are set in the then standard fashion of separated parts. In Cas the two voice parts are juxtaposed on facing pages. The upper voice (cantus) is written on the verso side and the lower voice (tenor) is notated on the recto of the following folio.

Table 1: Ugolino's compositions in $\mathrm{Cas}^{23}$

\begin{tabular}{|c|c|c|c|c|}
\hline Incipit & Genre & Folios (Pages) ${ }^{24}$ & Mise-en-page & \\
\hline Se videar & ballade & $343^{v}-344^{r}(679-680)$ & $\begin{array}{l}\text { cantus 1-6 } \\
\text { canon 6-7 }\end{array}$ & tenor $1-5$ \\
\hline L'alta virtute & ballata & $344^{v}-345^{r}(681-682)$ & $\begin{array}{l}\text { cantus } 1-8 \\
\text { residuum } 8\end{array}$ & $\begin{array}{l}\text { tenor } 1-5 \\
\text { canon } 5\end{array}$ \\
\hline Chi solo a si & ballata & $345^{v}-\left[346^{r}\right](683-[684])$ & $\begin{array}{l}\text { cantus } 1-8 \\
\text { residuum } 8\end{array}$ & [tenor] \\
\hline
\end{tabular}

All three compositions are notated in black mensural notation. However, all three songs also contain additional visual elements, namely coloration (notes in red ink) and proportion signs, which in all probability indicate the complex rhythms typical for Ars subtilior repertory. In the case of the ballade Se videar and the ballata L'alta virtute this can be stated with certainty because they exhibit canons, i.e. explanatory texts which give instructions on the interpretation of the proportion signs contained in the compositions. In the case of the last composition, the ballata Chi solo a si, the interpretation of the cantus, which features red and void red notation, is not straightforward, because the composition is incomplete. Folio

almost all folios the majority of music contained in the manuscript was undecipherable. Recently, Andreas Janke and John Nádas (2016) published a volume of multispectral images of all folios from the codex, which provide (partly) legible reconstructions of the original layer, thereby enabling further research on the repertory. The compositions by Ugolino contained in SL are edited and discussed in Janke 2016.

23 A similar table can be found in Janke 2016, 135 (table IV.1). It contains an error concerning the mise-en-page of Se videar, however.

24 The folios of the Cas manuscript contain three different sets of numbers. There is complete (most likely stamped) foliation in the lower right-hand margin of each recto, which is used by the Casanatense Library and which I therefore decided to refer to in this paper. Moreover, there is complete pagination in the upper right-hand corner of each recto, which Albert Seay used for his edition of the manuscript and which is given in brackets here. And finally, there is an early foliation, which has been cut away on many folios and therefore disregarded here.

25 The numbers in the two columns refer to the staves (five lines in red ink) on the folios. 
$346^{\mathrm{r}}$, which presumably contained the tenor, is missing from the manuscript. Due to water damage faint imprints of the note shapes from the recto of the missing folio are visible on folio $345^{v}$ (see Fig. 6). ${ }^{26}$ It might even be possible to reconstruct some parts of the second voice with the aid of multispectral imaging. Until then the meaning of red and void red notation in Chi solo a si remains in the realm of speculation. The following discussion therefore focuses on the two complete compositions, Se videar and L'alta virtute.

\section{Proportion signs in the Cas compositions}

The two songs contain ten different proportion signs. Several observations can be made from a comparison of the proportion signs and their interpretation ${ }^{27}$ as illustrated in Table 2:

1. Appearance: The proportion signs in the Cas compositions appear as six different single Arabic numerals and four different geometric shapes, namely circles and semicircles. ${ }^{28}$ As can be seen from Table 2, both songs contain single Arabic numerals as well as geometric shapes, i.e. neither composition strictly uses either one form or the other.

2. Congruence: Only two proportion signs have a concordant interpretation in the two pieces. The Arabic numeral 2 indicates dupla (2:1) proportion in both cases and the semicircle $\subset$ indicates sesquialtera (3:2) proportion.

3. Divergence: Two proportions appearing in both songs are indicated by different proportion signs. Tripla (3:1) proportion is indicated by the Arabic numeral 3 in Se videar but by the circle O in L'alta virtute. Sesquitertia (4:3) proportion is indicated by 8 in Se videar but by 4 in L'alta virtute. Furthermore, 4 is used to signal another proportion in Se videar, namely subdupla (1:2) proportion. And finally, the circle with one dot indicates sesquialtera

26 Cf. Janke 2016, 135.

27 The ratios given as interpretation of the proportion signs in the two songs operate at the minim level, i.e. minims are the rhythmic units compared to each other in the given ratio. For example, three minims replace two minims in sesquialtera (3:2) proportion. A comparison of minims in rhythmic proportions is common practice in Ars subtilior compositions. The two canons given in the two compositions confirm this since they also refer to minim level.

28 Anna Maria Busse Berger (1993, 183) erroneously mentions stacked Arabic numerals ('fractions') in pieces by Ugolino. However, stacked Arabic numerals neither appear in the Cas songs nor in Ugolino's $S L$ compositions. 
(3:2) proportion in Se videar but dupla sesquiquarta (9:4) proportion in L'alta virtute.

Table 2: Proportion signs and their interpretation in the Cas compositions

\begin{tabular}{lccccccccc}
\hline & $2: 1$ & $1: 2$ & $3: 1$ & $3: 2$ & $2: 3$ & $4: 3$ & $3: 4$ & $9: 2$ & $9: 4$ \\
\hline Se videar & 2 & 4 & 3 & $\odot$ and $\odot$ & 9 & 8 & 6 & & \\
L'alta virtute & 2 & & 0 & $\odot$ & & 4 & & $\odot$ & $\odot$ \\
& & & & & & & & & \\
\hline
\end{tabular}

It can be noted that the use of signs in the two compositions is not consistent in the sense that one particular proportion sign always indicates one rhythmic proportion. This accords with findings in other Ars subtilior manuscripts. ${ }^{29}$ The adaptation process of introducing notational innovations in compositions does not seem to have been standardised, even in the music by one composer. In Cas, this impression is reinforced by the presence of canons in both pieces. These canons present detailed instructions on the interpretation of the signs found in the compositions. It can therefore be assumed that even readers of the treatise were not expected to know how to interpret the proportion signs without additional explanation. Several of the proportion signs used do indeed call for such an additional explanation because their choice does not seem to be obvious. Indicating subsesquialtera (2:3) proportion by the Arabic numeral 9 and subdupla (1:2) proportion by the Arabic numeral 4 are examples for such choices.

\section{Comparing teachings and songs}

We will return to the compositions later in this paper. Prior to this, I would like to compare the proportion signs in the two compositions to Ugolino's statements concerning the notation of rhythmic proportions in the treatise. In his Declaratio Ugolino writes:

Moderni enim cantores volentes in suis cantibus notarum proportiones ostendere, signa
quaedam proportionibus conformia scribunt, nam si inter notas comparationem seu pro-
portionem facere volunt sexquitertiam hoc in canone signum $\frac{4}{3}$ subscribunt. [...] Si sexqui-

29 For more information on this issue see my $\mathrm{PhD}$ thesis (in preparation). 
alteram volunt significare proportionem hoc signum describunt $\frac{3}{2}$. [...] Possunt etiam multiplicatae proportiones huiusmodi per signa multiplicata significari, ut si fiat proportio in notis tripla, tripla in cifris proportio demonstretur hoc modo $\frac{3}{1}$, si quadrupla hoc modo $\frac{4}{1}$, et sic de ceteris. [...] Aliis etiam signis moderni cantores utuntur ostendendae diminutionis causa, quorum unus est semicirculus sua semicirculatione partem sinistram respiciens qui talis est $\mathrm{J}$, hoc enim signum ponunt moderni [...] et eum sexquitertiae proportioni attribuunt. Quidam vero alia signa ponunt, scilicet, semicirculos, quorum unus partem superiorem, alter partem inferiorem respicit, sub quibus diversas intelligunt proportiones, ut sub hoc semicirculo $\smile$ duplam faciunt proportionem, sub hoc $\frown$ subsexquialteram. Aliud etiam signum apponunt hoc, scilicet, $\diamond$, quatuor laterum pro quo sexquitertia utuntur proportione, sed nobis plus placet cifrarum positio qua proportionum clarior ostenditur demonstratio. In eis namque nulla deceptio, in his autem ambiguitas cadere potest et error. $^{30}$

Ugolino's description of proportion signs begins with the two most common rhythmic proportions, namely sesquitertia (4:3) and sesquialtera (3:2) proportion, which are indicated by the stacked Arabic numerals $\frac{4}{3}$ and $\frac{3}{2}$ respectively. He resumes with a description of proportions of the multiplex type: tripla (3:1) proportion indicated by $\frac{3}{1}$ and quadrupla (4:1) proportion signalled by $\frac{4}{1}$. The supplement et sic de ceteris suggests that all rhythmic proportions may be indicated by stacked Arabic numerals. Ugolino then continues by stating that the reversed

30 'If modern cantors want to show proportional notes in their chants, they write signs to emphasise such proportions, so if they want to make a sesquitertia proportion between notes they write this sign $\frac{4}{3}$ in the canon. [...] If they want to indicate sesquialtera proportion, then they will write $\frac{3}{2}$. [...] Even multiplex proportions can thus be signified by multiplex signs, so that if the proportion in the notes will be tripla, tripla in proportion figure shall be demonstrated in this way $\frac{3}{1}$, quadrupla in this way $\frac{4}{1}$, and so on. [...] The modern cantors, incidentally, use other signs to show diminution, one of these is the semicircle, whose semicircle part looks back left, which is [written] like this J. This sign is placed by the moderni [...] and they attribute sesquitertia proportion to it. Certain people use other signs, namely semicircles, of whom one faces the upper part and the other one the lower part, and in them they distinguish different proportions, so that in this semicircle $\cup$ they make dupla proportion and in this $\frown$ subsesquialtera [proportion]. Again, others place this sign $\diamond$, four of these sides are used for the sesquitertia proportion. But we prefer to use of numbers, because with them we can show the proportions more clearly. In them there is no deception, in these others there can be ambiguity and error.' Declaratio, Book 3 , Chapter VI: 'De signis', article 7 (edition in Seay 1960, 210-211). 
semicircle $\supset$ indicates diminution and that this diminution also results in sesquitertia (4:3) proportion. Other semicircles are also mentioned: $\smile$ indicates dupla (2:1) proportion and $\frown$ signals subsesquialtera (2:3) proportion. Finally, Ugolino declares that a diamond-shaped sign $(\diamond)$ may also indicate sesquitertia (4:3) proportion but that he would recommend the use of numerals, i.e. stacked Arabic numerals, because they are less ambiguous than the other signs.

A direct comparison with the statements on proportion signs from the Declaratio reveals that none of the signs described in the treatise matches those found in the two pieces (see Table 3).

Table 3: Comparison of proportion signs in Ugolino's Declaratio and his compositions in Cas

\begin{tabular}{lcccccccccc}
\hline & $2: 1$ & $1: 2$ & $3: 1$ & $4: 1$ & $3: 2$ & $2: 3$ & $4: 3$ & $3: 4$ & $9: 2$ & $9: 4$ \\
\hline Declaratio & $\smile$ & & $\frac{3}{1}$ & $\frac{4}{1}$ & $\frac{3}{2}$ & $\frown$ & $\frac{4}{3}$ or $\supset$ or $\diamond$ & & & \\
Se videar & 2 & 4 & 3 & & $\lessdot$ and $\odot$ & 9 & 8 & 6 & & \\
L'alta virtute & 2 & & 0 & $\odot$ & 4 & & $\odot$ & $\odot$ \\
\hline
\end{tabular}

Out of the eight proportion signs depicted in the Declaratio only one sign, namely the reversed semicircle J, frequently appears in Ars subtilior compositions, though not in the three songs in Cas. In the majority of cases, J indicates sesquitertia (4:3) proportion - this interpretation is also given in the treatise - and it can even be found in Ugolino's ballata La vista di costei from the San Lorenzo codex $(S L)$, though its meaning there is unclear due to poor legibility. ${ }^{31}$

The stacked Arabic numerals mentioned by Ugolino are a common form for the visualisation of ratios in the late Middle Ages and early Renaissance and they can be found in numerous texts in which rhythmic proportions are discussed. ${ }^{32}$ The notation of ratios as $\mathrm{x}$ :y only came into use in the seventeenth century. ${ }^{33}$ Nevertheless, stacked Arabic numerals only appear in a handful of Ars subtilior compositions and they are much less common than single Arabic numerals. ${ }^{34}$ It

31 Cf. Janke 2016, 46-47.

32 See my PhD thesis (in preparation). Within texts, however, proportions are most commonly referred to by their Latin names dupla, tripla, sesquialtera, sesquitertia, etc.

33 Cf. Baxandall 1972, 95.

34 Among these are Petrus de Goscalch's En nul estat, Anthonello de Caserta's Dame d'onour, en qui tout mon cuer maynt and Amour m'a le cuer mis en tel martire, and Baude Cordier's two 
is telling that no stacked Arabic numerals can be found in Ugolino's surviving oeuvre and that the Cas compositions contain six different single Arabic numerals.

Most remarkably, we can find two semicircles ( $\cup$ and $\frown$ ) in Ugolino's description which seldom if ever appear in surviving Ars subtilior music manuscripts. ${ }^{35}$ Dupla (2:1) proportion is usually expressed by the single Arabic numeral 2 - as in the two Cas compositions - and subsesquialtera (2:3) proportion is most often applied in order to revoke sesquialtera (3:2) proportion, in which case the sign for the initial mensuration is used again. ${ }^{36}$ In Se videar, subsesquialtera (2:3) proportion is indicated by the Arabic numeral 9. And finally, the diamond-shaped sign $(\diamond)$ would be most unsuitable for the indication of proportion in notated music because it has the exact same shape as the semibreve and would therefore not be distinguishable from the notes. ${ }^{37}$ Ugolino even remarks upon this ambiguity: 'in

rondeaux Tout par compas and Belle, bonne, sage. Of these five works only the Cordier compositions and Caserta's Amour m'a le cuer mis en tel martire employ stacked Arabic numerals as proportion signs. In Goscalch's ballade and Caserta's Dame d'onour, en qui tout mon cuer maynt stacked Arabic numerals are used as alternative mensuration signs (see note 36 for an explanation of the term).

35 I am only aware of one Ars subtilior music source using the semicircle opened at the top ( $\backsim)$, namely the Boverio codex (Turin, Biblioteca Nazionale Universitaria, T.III.2), where $\cup$ appears in Johannes Suzoy's ballade Pytagoras, Jobal et Orpheus- indeed indicating dupla (2:1) proportion as stated in Ugolino's treatise. Cf. Stoessel 2010, 325. Stoessel (2010, 342) has already remarked upon the fact that the transmissions of Suzoy's ballade in Chantilly, Musée Condé, 564 and Paris, Bibliothèque nationale de France, nouvelles acquisitions françaises 22069 contain written instructions underneath the music instead of $\smile$. The semicircle $\frown$ does - to my knowledge - not appear in any surviving Ars subtilior music manuscript.

36 Mensuration signs indicate the mensuration of a certain piece or parts thereof. Mensurations describe the proportional relationship between notes of different note values and can be compared to meters in modern notation. Unlike today, where meters are always indicated at the beginning of a composition, e.g. ${ }_{4}^{4}$, mensurations are rarely indicated in mensural music and have to be deduced from the context. In medieval music, the proportional relationship of one note value to that of a smaller degree can be binary or ternary. In imperfect time (tempus imperfectum), the breve (notated as black square) is worth two semibreves (notated as diamonds). In perfect time (tempus perfectum), on the other hand, the breve contains three semibreves. Other relationships can be binary or ternary according to the same principle. The relationship between semibreve and minim (notated as diamond with stem) is referred to as prolatio, which is either maior or minor.

37 It should be noted that the sign $(\diamond)$ is void and not full black - at least in the Cas version of the Declaratio. One wonders whether Ugolino meant that void notation in general would indicate sesquitertia (4:3) proportion. But then he would more likely have given a minim instead of a 
his autem ambiguitas cadere potest et error. ${ }^{38}$ But why does Ugolino describe seven proportion signs, which do not reflect on contemporary notational practice, and only one sign (כ), which is actually being used in Ars subtilior music?

The third book of the Declaratio, in which we can find the above description on the different ways to notate proportional rhythms, ${ }^{39}$ is in large parts a commentary on the famous music treatise Libellus cantus mensurabilis (henceforth Libellus) of c. 1340, generally attributed to Johannes de Muris, which was written almost a century before the Declaratio. Proportion signs do not appear in the music of Johannes de Muris' time. Hence, Ugolino's description of proportion signs represents an adaptation to the Libellus, which takes into account recent developments in music notation, namely the use of proportion signs in Ars subtilior music. ${ }^{40}$ However, in practice these proportion signs were not used in a standardised manner, which is also reflected in the two Cas compositions. It is conceivable that descriptions of proportion signs in music treatises were a reaction to their inconsistent use in music notation. These discussions of notational devices to indicate rhythmic proportion might actually have been intended to standardise music notation.

It stands to reason that Ugolino's adaptation in the Declaratio should be regarded as a suggestion for a future notation practice rather than representation of a contemporary practice, which was not standardised. The fact that he recommends the use of numbers rather than other signs by arguing that numbers are less ambiguous points towards the intention to achieve more clarity and consistency in music notation..$^{41}$ After elaborating on these preferred stacked Arabic numerals he moves on to describing the only proportion sign in Ars subtilior music, which has a rather consistent meaning, namely the reversed semicircle J,

semibreve. Moreover, coloration of notes and its interpretation is discussed elsewhere in the same chapter. Cf. Declaratio, Book 3, Chapter VI: 'De signis', article 7, phrases 29-33 (edition in Seay 1960, 211-212).

38 Reference and translation in note 30 above.

39 The full version of the third book of Ugolino's Declaratio, which other than the abridged version contains this description, is transmitted in five different manuscripts (see MacCarthy 2014, 424-425 for details).

40 Even before 1430, J is discussed in music treatises as a proportion sign indicating sesquitertia (4:3) proportion. Ugolino is therefore not the first person to mention $\supset$ in writings on music even though the mention of the sign is an adaptation to the Libellus. The same is true for stacked Arabic numerals. Stacked Arabic numerals as proportion signs as well as the reversed semicircle $J$ are already discussed in Prosdocimus de Beldemandis' Expositiones tractatus practice cantus mensurabilis magistri Johannis de Muris of 1404.

41 '[...] nobis plus placet cifrarum positio qua proportionum clarior ostenditur demonstratio.' Reference and translation in note 30 above. 
which commonly indicates sesquitertia (4:3) proportion. ${ }^{42}$ The semicircle $C$ also exists in music notation, but it usually does not have a proportional meaning. It indicates the mensuration tempus imperfectum with prolatio minor. With $\mathrm{J}$ and $\mathrm{C}$ already established in music notation, isn't it conceivable that Ugolino simply added the other two semicircles ( $\smile$ and $\frown$ ) and attributed contrived interpretations to these signs? They might also have been derived from diagrams of intervals, in which proportions are often displayed as arches. In any case, the description of the two semicircles $\smile$ and $\frown$ may also be regarded as suggestion for future music notation. As to why he decided to include a sign $(\diamond)$ in his description, which is - as already stated - completely unsuitable for the use in practical music remains unclear to me. Unfortunately, I have been unable to find this sign in contexts other than music.

As established above, the proportion signs described in the Declaratio do not appear in the compositions in Cas, and - with the exception of $\supset$ - very rarely or not at all in other Ars subtilior music manuscripts. However, there is an overlap between the Declaratio and the ballata L'alta virtute concerning the notation of rhythmic proportions which I would like to discuss in the remainder of this paper.

L'alta virtute contains a proportion sign which is rarely used in Ars subtilior music, namely a circle with three dots $\odot$ indicating quadrupla sesquialtera (9:2) proportion. To my knowledge, the sign only appears in two anonymous ballades in the manuscript Turin, Biblioteca Nazionale Universitaria, J.II.9 and the ballade Le sault perilleux by J. Galiot in Chantilly, Musée Condé, 564 . However, $\odot$ is regularly featured in music treatises, where it is often discussed as mensuration sign ${ }^{43}$ indicating tempus perfectum with prolatio maior (ternary division of both breve and semibreve, comparable to a $9 / 8$ meter) ${ }^{44}$ In fact, it is described by Ugolino as preferable to the more common sign $\odot$ for this particular mensuration:

Quidam vero ignari peritiae pro tribus in quadrangulo tractulis ad modi minoris ostendendam perfectionem, uno duntaxat utuntur tractulo et ad minoris imperfectionem modi nullo penitus utuntur. Similiter in significanda prolatione maiori pro punctis tribus uno utuntur et in minori pro duobus nullo. Hi namque nulla ratione fundati quod agunt penitus ignorant, nam numerus ternarius pro significanda perfectione positus perfectus est, et binarius pro imperfectione imperfectus. Perfectionem igitur et imperfectionem ii numeri continent

42 There are only a handful of alternative interpretations of $\supset$ in Ars subtilior music. For details see my $\mathrm{PhD}$ thesis (in preparation).

43 See note 36 above for an explanation of the term.

44 A list of treatises describing $\odot$ as sign for tempus perfectum with prolatio maior can be found in Busse Berger 1993, 236-237. Among the authors are some of Ugolino's contemporaries: Johannes Ciconia (d. 1412), Prosdocimus de Beldemandis (d.1428), and Giorgio Anselmi (d. c. 1440-1443). 
et important, sed unitas quae pars numeri est et non numerus perfectionem vel imperfectionem nullatenus significare potest, ergo unus tractulus quem isti ponunt pro tribus, vel unus punctus nec modi nec prolationis significant perfectionem. Similiter ex nihilo nihil fit, igitur ex nullo signo nulla mensurae imperfectio potest significari, cuius oppositum isti ponunt. ${ }^{45}$

According to Ugolino, the indication of major prolation by a single dot in a circle or semicircle is refutable because the value 1 - thought of as 'unity' - is not a number. Similarly, a void space in a circle or semicircle cannot represent minor prolation because a void space is 'nothing' and therefore cannot indicate anything. The customary signs $\odot, O, \subset$ and C, which are even found in Ugolino's own compositions, are rejected. In this example, we can observe another discrepancy between music notation described in treatises and actual notational practice. The statements in the treatise are clearly influenced by philosophical doctrine, especially the statement according to which a void space in a circle cannot indicate anything. The existence of the more common form of mensuration signs with one or no dot is acknowledged, but their use is attributed to less talented composers.

By using $\odot$ in L'alta virtute, is Ugolino taking the above statements into consideration? The answer is: probably not. Regarding the proportion signs used in L'alta virtute in order of their appearance, we can observe that the more common forms of circles and semicircles with one or no dot are used first (see Fig. 1).

45 'Certain people, wanting in skill, in order to show perfection in minor modus, employ only one tail in a quadrangle instead of three, and, in order to show imperfection in minor modus, employ none. Similarly in signifying prolatio maior, instead of three points they use one and in showing prolatio minor use none. These people do not know any reason by which they do this, for a ternary number placed for the signifying of perfection is perfect, and a binary one for imperfection [is] imperfect. Therefore these numbers contain and impart perfection and imperfection, but unity, which is a part of a number and not a number, can in no way signify perfection or imperfection. Therefore one tail, which they use instead of three, or one point signify neither perfection of the modus nor prolatio. Similarly nothing is made from nothing, therefore from a sign showing nothing no perfection of mensuration can be signified, whose opposite these people put forward.' Declaratio, Book 3, Chapter VI: 'De signis', article 2 (edition in Seay 1960, 200201; translation taken from Seay 1955, 154). 


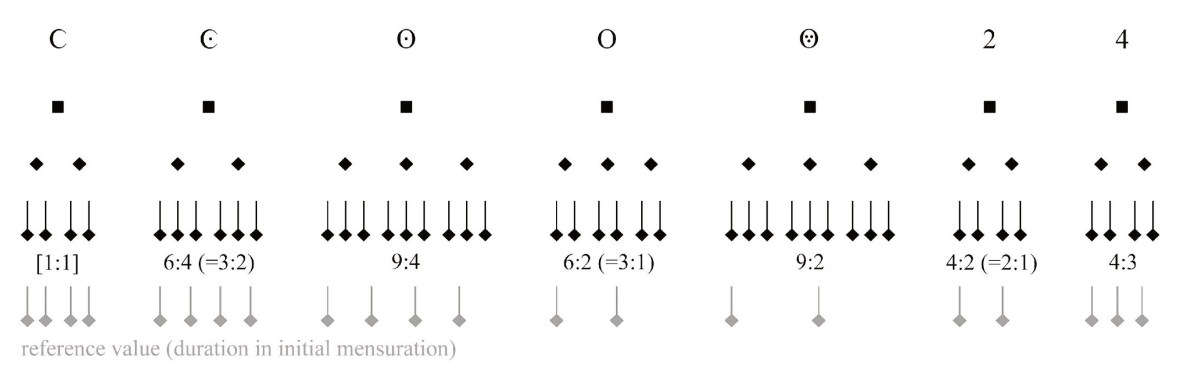

Fig. 1: Proportion signs and their interpretation in L'alta virtute in order of their appearance.

All geometric shapes in the ballata function as proportion signs as well as mensuration signs, i.e. the general distribution of semibreves and minims is changed under each sign in addition to them having a proportional meaning. The mensuration first changes from the initial tempus imperfectum with prolatio minor (C) to tempus imperfectum with prolatio maior $(\odot)$. Breve equivalence leads to a proportional change at the minim level: Three minims under $\odot$ replace two in C. Subsequently, the mensuration changes to tempus perfectum with prolatio maior, which is indicated by the common sign $\odot$. With breve equivalence still operating, the proportional change at the minim level is 9:4. After a change to yet another mensuration (tempus perfectum with prolatio minor indicated by 0 ) the ballata returns to tempus perfectum with prolatio maior. This time, however, diminution is also involved, i.e. the breve under $\odot$ is equivalent to a semibreve in the initial mensuration in C. Ugolino therefore needed an alternative sign for $\odot$, because he already used the circle with the single dot for the indication of dupla sesquiquarta (9:4) proportion. He reverts to the sign $\odot$, which the treatise praises as superior to the circle with the single dot, only in need of an alternative. This demonstrates that despite the statements in the treatise, the sign $\odot$ is still only number-two choice in music notation.

\section{Conclusion}

The comparison of music treatise and songs in the Cas manuscript has shown that the adaptation processes in music notation, i.e. the introduction of proportion signs, and the discussion thereof in music treatises are not as interrelated as might be expected. We can observe a high amount of divergence between Ugolino's statements on proportion and mensuration signs on the one hand and the signs used in the compositions transmitted in Cas on the other hand. 
Apparently, the adaptations in music notation and in music treatises proceeded independently of each other. Common ground can only be established on two very general levels: 1) In music treatises, proportions are not only discussed from a speculative perspective but also in chapters which discuss practical matters, such as music notation. Authors adapt the concept of proportio - hitherto only applied to intervals - to rhythm. This corresponds with developments in music notation, in which proportions are applied on rhythmic levels. 2) Music notation in Ars subtilior sources features notational innovations, namely new note shapes, notes in differently coloured ink, and proportion signs. Simultaneously, signs for the depiction of proportional rhythms are discussed in music treatises. However, we can find discrepancies between music treatises and Ars subtilior compositions even when they are attributed to the same author.

The proportion signs discussed in the sixth chapter of the third book of the Declaratio seem for the greater part to have been adopted from other contexts. They may have a speculative background, as stacked Arabic numerals or fractions respectively have their origin in arithmetic and the two unusual semicircles resemble arches used in the depiction of intervals. Out of the eight proportion signs which Ugolino mentions only the reversed semicircle $\supset$ is commonly used in Ars subtilior compositions, though not in the Cas songs. The discussion of stacked Arabic numerals could be interpreted as attempt to achieve more clarification in the future, but we can observe that the use of single Arabic numerals is still the prevalent custom in music notation. Disregard of the instructions in the treatise can also be discerned in the use of mensuration signs with one dot or without a dot instead of signs with three or two dots. As has been shown, the sign with three dots is only reverted to on rare occasions. In the case of Cas, it was the need for an alternative sign for tempus perfectum with prolatio maior $(\odot)$, because $\odot$ was already used for another purpose. This example as well as the inconsistent use of signs in the two compositions demonstrate that proportion signs seem to have been chosen more or less arbitrarily according to their availability. This pragmatic approach contrasts with the theoretical approach in the Declaratio.

The discrepancies between statements in music treatises and notational practice discussed in this paper should particularly be taken into account when treatises are consulted for the purpose of interpreting devices of rhythmic notation in compositions. Several sources of Ars subtilior music are incomplete or partly illegible, for example because of water damage or scraping, in which case scholars often draw on contemporary treatises in order to provide partial transcriptions and editions. This is even true for Cas. In his discussion of the incomplete ballata Chi solo a si transmitted on the last folio of the manuscript, Albert Seay turned towards Ugolino's Declaratio for guidance on the interpretation of 
coloured notes in the composition. ${ }^{46}$ As I will explain elsewhere, however, Ugolino's statements cannot be applied to red void notation in the song. ${ }^{47}$ Not least to caution against such approaches, this paper has aimed to establish that discussions of music notation in treatises and actual notational practice should be regarded in their context and are not necessarily congruent.

Teaching materials which offer instructions on the notation of mensural music, such as the third book of Ugolino's Declaratio, exhibit strong influences of quadrivial scholarship. Hence, these instructions sometimes contradict conventions in musical notation. It seems probable that the adaptation of the concept proportio to rhythm - manifested in Cas in the discussion of proportion signs was strongly influenced by speculative paradigms that were not connected to practical music. Simply put, the teachings on the notation of complex rhythms seem to have been applied only rarely in music notation. It is telling that even compositions which are part of a manuscript transmitting teaching materials do not implement the instructions found therein. The manuscript Cas thus provides rare insights into the differences between these two traditions.

\section{Acknowledgements}

The research for this article was carried out within the scope of the work conducted by the SFB 950 'Manuskriptkulturen in Asien, Afrika und Europa' / Centre for the Study of Manuscript Cultures (CSMC) funded by the German Research Foundation (Deutsche Forschungsgemeinschaft, DFG).

\section{References}

Apel, Willi (1942), The Notation of Polyphonic Music 900-1600, Cambridge, MA: Mediaeval Academy of America.

Baxandall, Michael (1972), Painting and Experience in Fifteenth Century Italy: A Primer in the Social History of Pictorial Style, Oxford: Clarendon.

Busse Berger, Anna Maria (1993), Mensuration and Proportion Signs: Origins and Evolution, Oxford: Clarendon.

D’Accone, Frank A. (1984), 'Una nuova fonte dell’Ars nova italiana: il codice di San Lorenzo 2211', Studi Musicali, 13: 3-31.

Dyer, Joseph (2007), 'The Place of Musica in Medieval Classifications of Knowledge', The Journal of Musicology, 24: 3-71.

46 The discussion of the three compositions can be found in Seay 1955, 152-162.

47 See my $\mathrm{PhD}$ thesis (in preparation). 
Fallows, David (1996), 'The End of the Ars Subtilior', in Peter Reidemeister (ed.), Basler Jahrbuch für historische Musikpraxis 20, Winterthur: Amadeus, 21-40.

Fallows, David (2010), A Catalogue of Polyphonic Songs, 1415-1480: Update. <https://personalpages.manchester.ac.uk/staff/david.fallows/appendix.pdf> (accessed on 13 Nov. 2020).

Gallo, F. Alberto (ed.) (1966), Prosdocimi de Beldemandis opera 1: Expositiones tractatus pratice cantus mensurabilis magistri Johannis de Muris, Bologna: Università degli Studi de Bologna, Istituto di Studi Musicali e Teatrali.

Gallo, F. Alberto (1984), 'Die Notationslehre im 14. und 15. Jahrhundert', in Hans Heinrich Eggebrecht et al. (eds), Die Mittelalterliche Lehre von der Mehrstimmigkeit, Darmstadt: Wissenschaftliche Buchgesellschaft, 257-356.

Günther, Ursula (1963), 'Das Ende der Ars nova', Die Musikforschung, 16: 105-120.

Haas, Max (1982), 'Studien zur mittelalterlichen Musiklehre I: Eine Übersicht über die Musiklehre im Kontext der Philosophie des 13. und frühen 14. Jahrhunderts', in Wulf Arlt (ed.), Aktuelle Fragen der musikbezogenen Mittelalterforschung: Texte zu einem Basler Kolloquium des Jahres 1975, Winterthur: Amadeus, 323-427.

Haberl, Franz X. (1895), 'Bio-bibliographische Notizen über Ugolino von Orvieto', Kirchenmusikalisches Jahrbuch, 10: 40-49.

Herlinger, Jan (2001), 'Music Theory of the Fourteenth and Early Fifteenth Centuries', in Reinhard Strohm and Bonnie J. Blackburn (eds), Music as Concept and Practice in the Late Middle Ages, New York: Oxford University Press, 244-300.

Hufnagel, Elisabeth (in preparation), Musical Notation between Individualisation and Standardisation: Proportion Signs in the Manuscripts of the So-called Ars subtilior, PhD thesis, University of Hamburg.

Janke, Andreas (2016), Die Kompositionen von Giovanni Mazzuoli, Piero Mazzuoli und Ugolino da Orvieto im San-Lorenzo-Palimpsest (ASL 2211), Hild esheim: Georg Olms.

Janke, Andreas and John Nádas (eds) (2016), The San Lorenzo Palimpsest Florence, Archivio del Capitolo di San Lorenzo Ms. 2211: Introductory Study and Multispectral Images, Lucca: LIM.

Lockwood, Lewis (2009), Music in Renaissance Ferrara 1400-1505: The Creation of a Musical Center in the Fifteenth Century, Oxford: Oxford University Press.

MacCarthy, Evan A. (2014), 'The Sources and Early Readers of Ugolino of Orvieto's Declaratio Musice Discipline', in Marco Gozzi et al. (eds), Beyond 50 Years of Ars Nova Studies at Certaldo 1959-2009, Lucca: LIM, 401-425.

MacCarthy, Evan A. (2015), Reading the Blank Pages. <http://www.musicologynow.org/2015/ 12 /reading-blank-pages.html> (accessed on 30 Nov. 2020).

Reimer, Erich (1978), 'Musicus und Cantor: Zur Sozialgeschichte eines musikalischen Lehrstücks', Archiv für Musikwissenschaft, 35: 1-32.

Seay, Albert (1955), 'Ugolino of Orvieto, Theorist and Composer', Musica Disciplina, 9: 111-166.

Seay, Albert (ed.) (1960), Ugolino of Orvieto: Declaratio musicae disciplinae II, Rome: American Institute of Musicology.

Stoessel, Jason (2010), 'Looking Back Over the “Missa L’Ardant desir”: Double Signatures and Unusual Signs in Sources of Fifteenth-Century Music', Music \& Letters, 91: 311-342.

Tanay, Dorit (1999), Noting Music, Marking Culture: The Intellectual Context of Rhythmic Notation, 1250-1400, Holzgerlingen: Hänssler. 


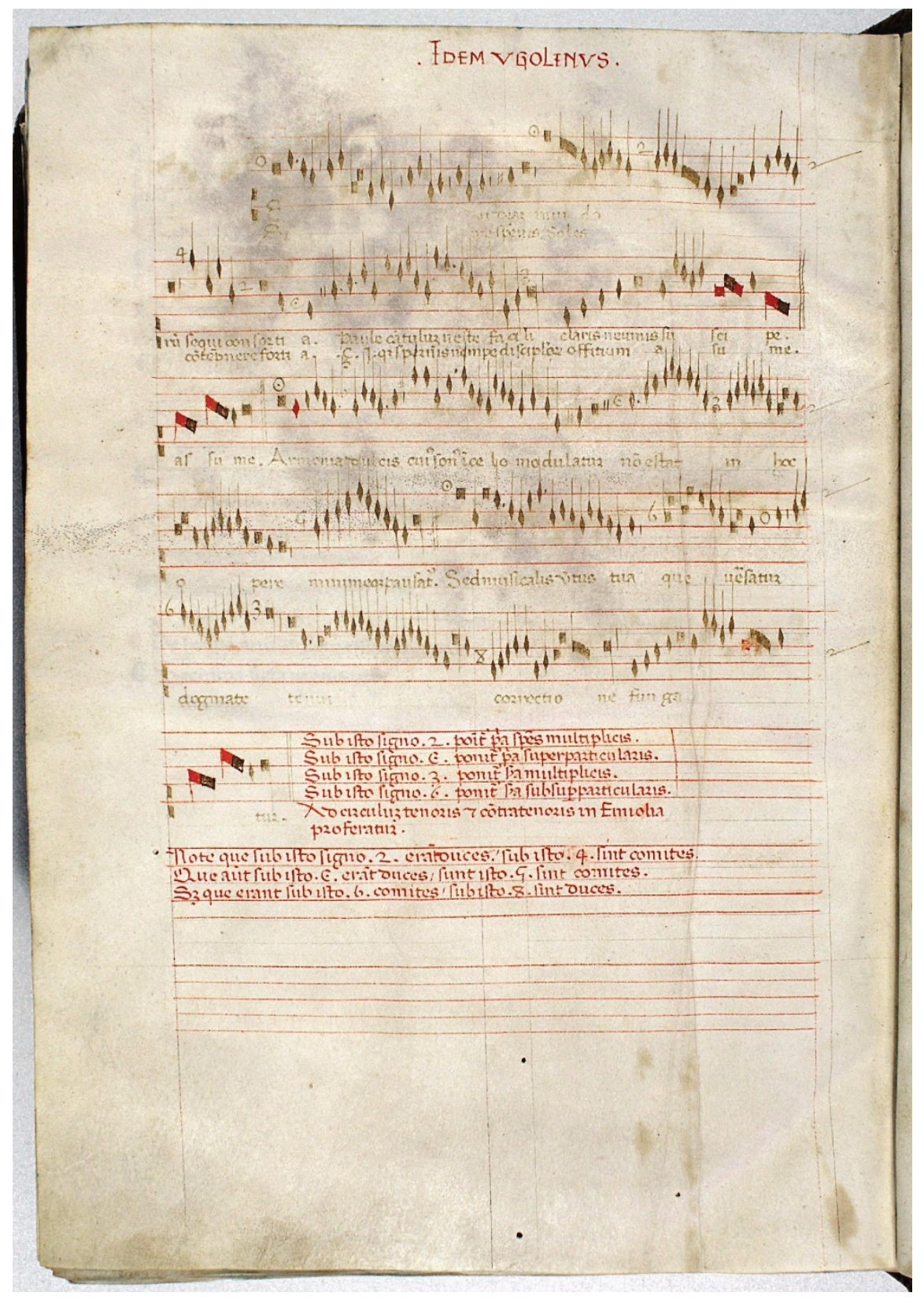

Fig. 2: Rome, Biblioteca Casanatense, 2151, fol. 343ำ (p. 679); Cantus of Se videar; (c) Biblioteca Casanatense, Rome. 


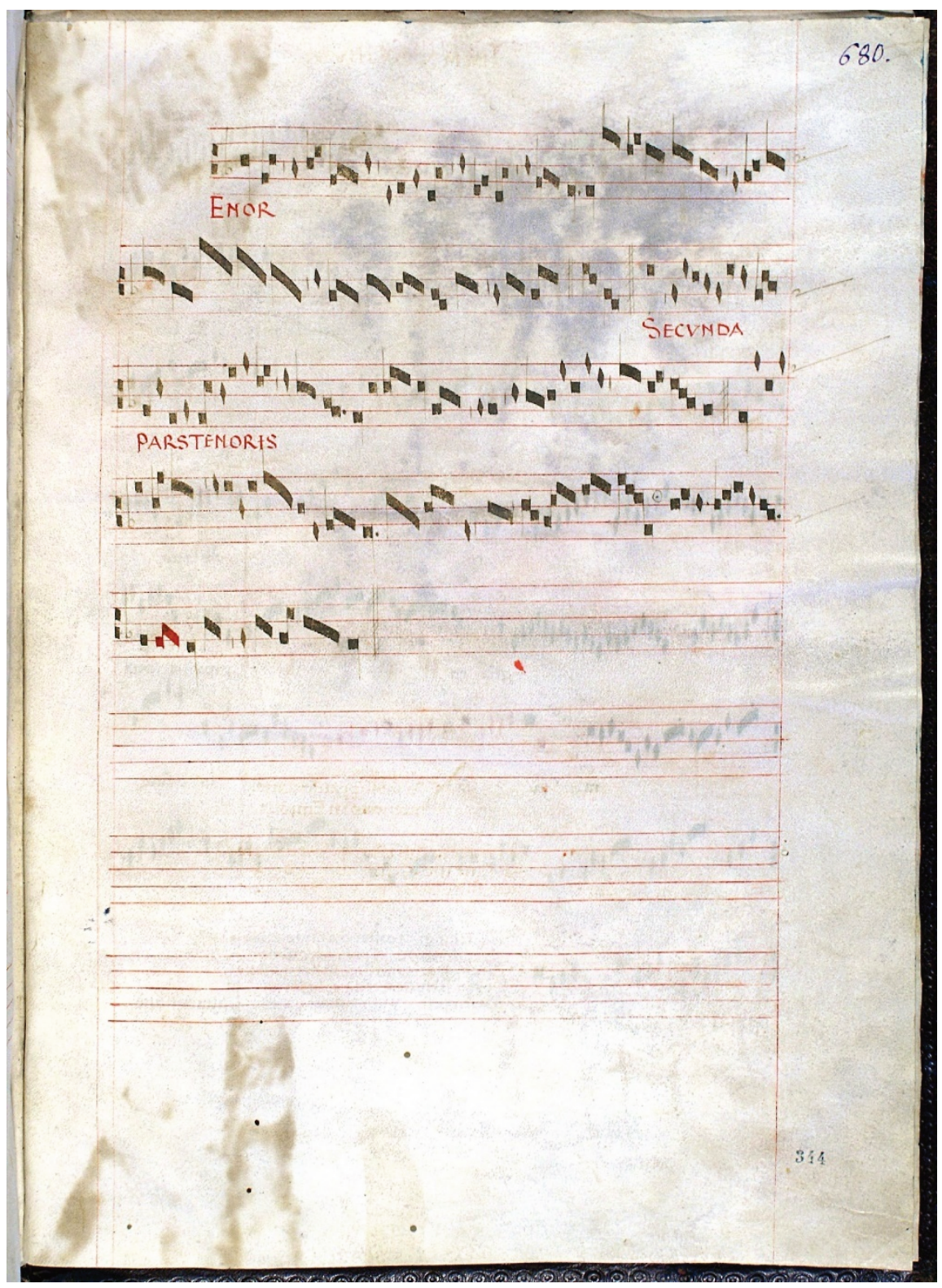

Fig. 3: Rome, Biblioteca Casanatense, 2151, fol. $344^{r}$ (p. 680); Tenor of Se videar; (c) Biblioteca Casanatense, Rome. 


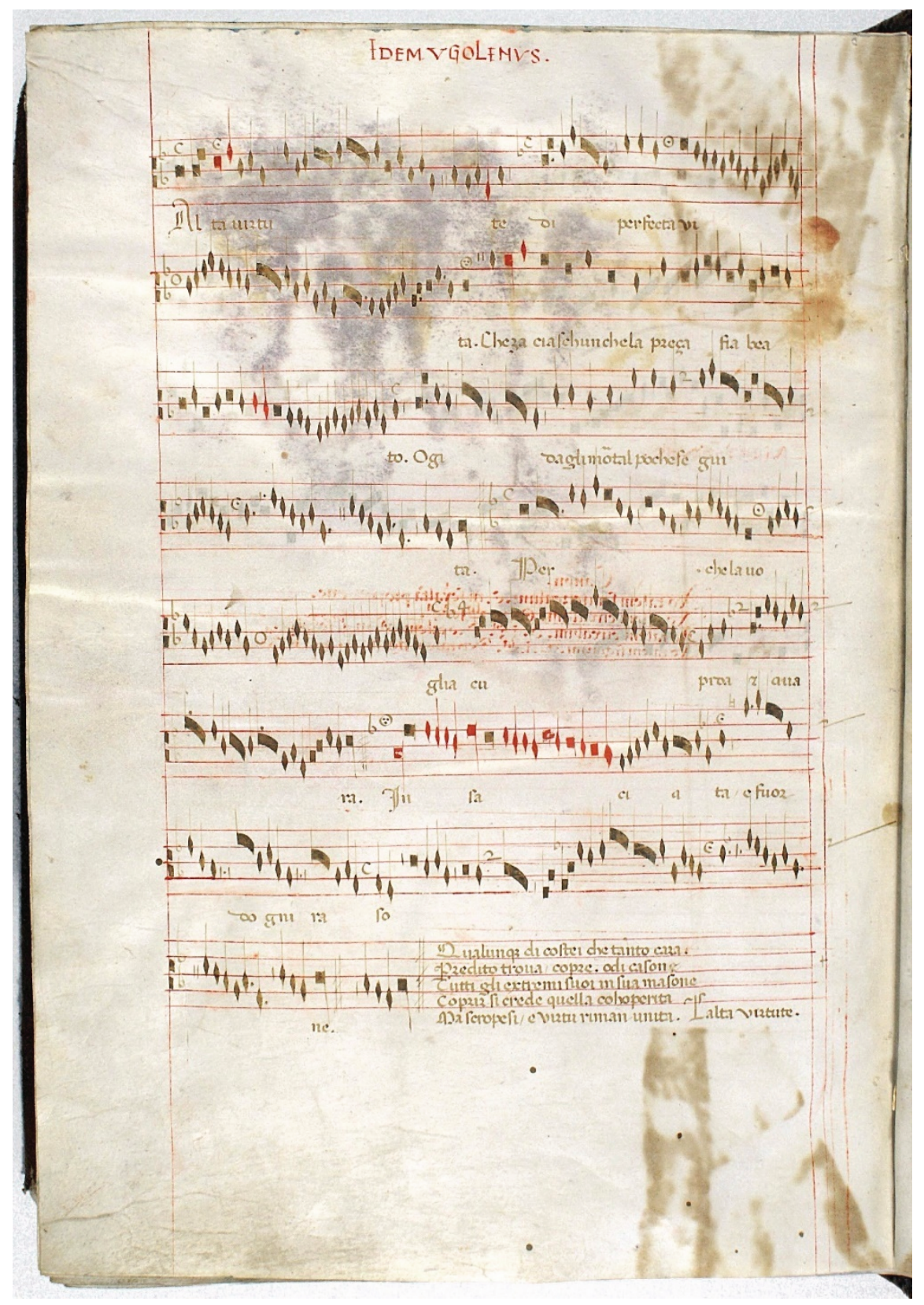

Fig. 4: Rome, Biblioteca Casanatense, 2151, fol. 344 (p. 681); Cantus of L'alta virtute; (c) Biblioteca Casanatense, Rome. 


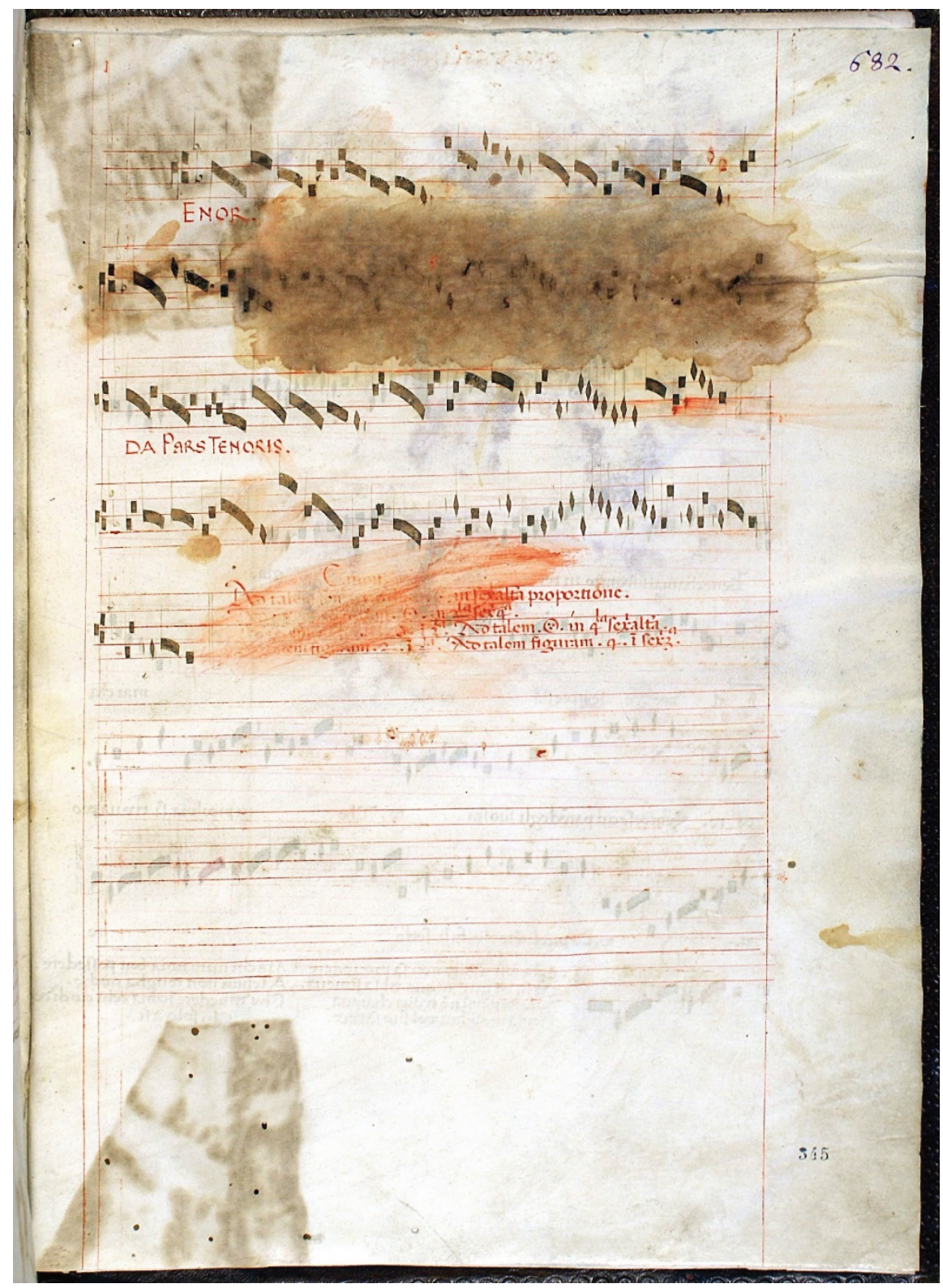

Fig. 5: Rome, Biblioteca Casanatense, 2151, fol. 345 ${ }^{\mathrm{r}}$ (p. 682); Tenor of L'alta virtute; (C) Biblioteca Casanatense, Rome. 


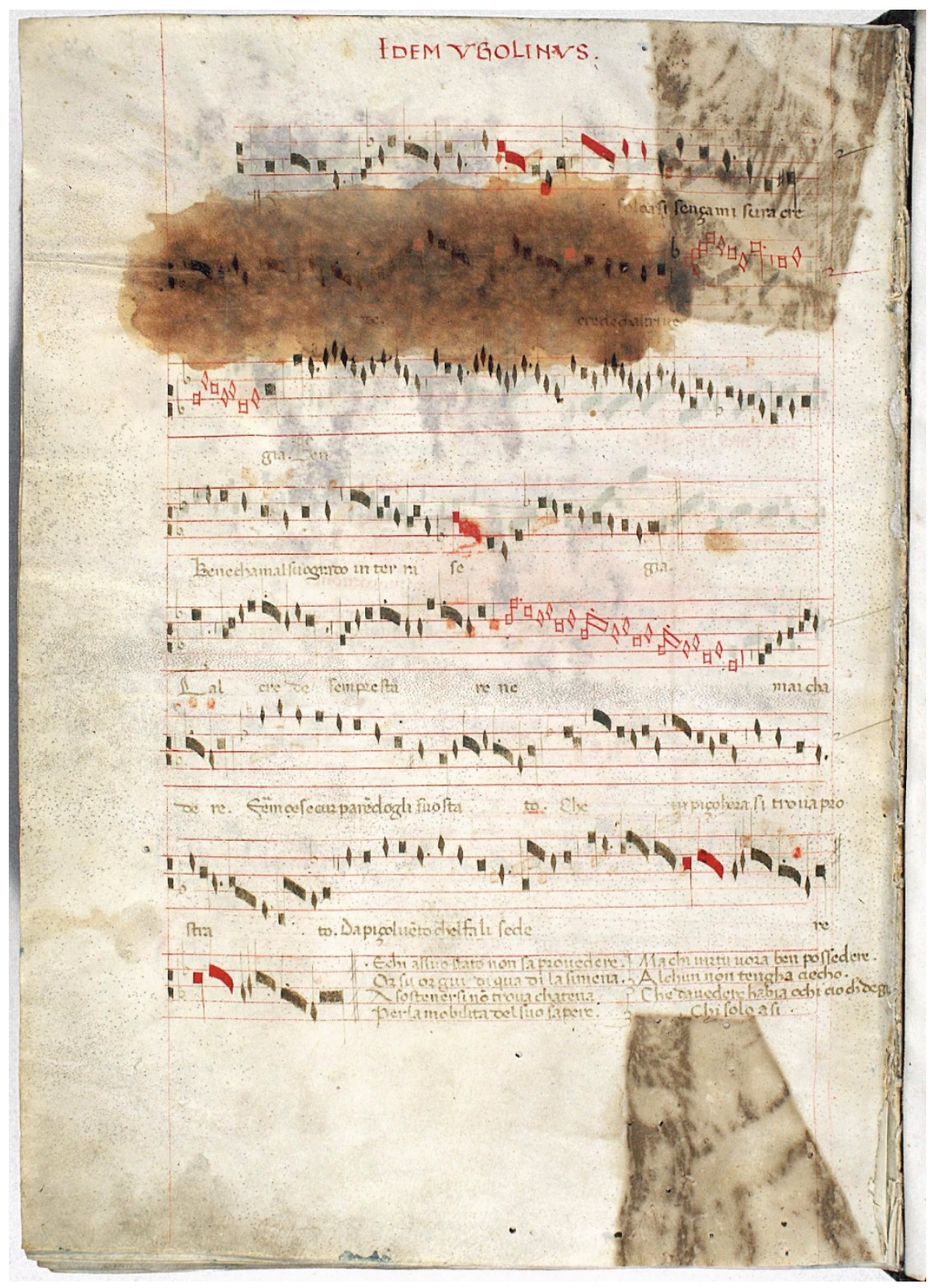

Fig. 6: Rome, Biblioteca Casanatense, 2151, fol. 345ำ (p. 683); Cantus of Chi solo a si; (C) Biblioteca Casanatense, Rome. 